\title{
Depletion of the Ozone Layer and Its Consequences: A Review
}

\author{
Anjali Aggarwal ${ }^{1}$, Reeta Kumari ${ }^{1}$, Neeti Mehla ${ }^{1}$, Deepali ${ }^{1}$, Rishi Pal Singh ${ }^{2}$, Sonal Bhatnagar ${ }^{3}$, \\ Kameshwar Sharma ${ }^{4}$, Kuldeep Sharma ${ }^{5}$, Amit Vashishtha ${ }^{1}$, Brijesh Rathi ${ }^{2 *}$ \\ ${ }^{1}$ Department of Botany, Sri Venkateswara College, University of Delhi, New Delhi, India; ${ }^{2}$ Department of Chemistry, Sri Venkates- \\ wara College, University of Delhi, New Delhi, India; ${ }^{3}$ Department of Botany, Deshbandhu College, University of Delhi, New Delhi, \\ India; ${ }^{4}$ Department of Biochemistry Sri Venkateswara College, University of Delhi, New Delhi, India; ${ }^{5}$ Department of Botany, Uni- \\ versity of Delhi, New Delhi, India. \\ Email: *rathi56@yahoo.co.in
}

Received July $11^{\text {th }}, 2013$; revised August $12^{\text {th }}, 2013$; accepted September $12^{\text {th }}, 2013$

Copyright (C) 2013 Anjali Aggarwal et al. This is an open access article distributed under the Creative Commons Attribution License, which permits unrestricted use, distribution, and reproduction in any medium, provided the original work is properly cited.

\begin{abstract}
Ozone $\left(\mathrm{O}_{3}\right)$ is a stratospheric layer that plays important role in providing support to humans for their survival. It is an essential factor for many global, biological and environmental phenomena. The ultra-violet (UV) rays emitted from sun are captured by ozone and thereby provide a stable ontological structure in the biosphere. Various anthropogenic activities such as emissions of CFCs, HCFCs and other organo-halogens lead to the depletion of ozone. The ozone depletion resulted in secondary production of an ozone layer near the ground (terrestrial ozone layer), which is responsible for adverse effects on plants, humans and environment with increased number of bronchial diseases in humans. The mutations caused by UV rays result in variation in morphogenic traits of plants which ultimately decreases crop productivity. However, UV radiation is required in optimum intensity for both plants and animals. This review takes into an account the wide ranging effects of ozone depletion with a majority of them being detrimental to the plant system.
\end{abstract}

Keywords: Ozone Depletion; Ultra-Violet Radiation; Chlorofluorocarbons; Plants; Ecosystem

\section{Introduction}

Some 2 billion years ago, rising atmospheric oxygen concentrations helped Earth's atmosphere to build up ozone and gradually led to the formation of the stratosphere. The photo-dissociation of oxygen molecules by highenergy solar photons $(175-242 \mathrm{~nm})$ in the stratosphere results in the production of ozone. This process leads to the release of single oxygen atoms which later combine with intact oxygen molecules to form ozone [1].

Ozone $\left(\mathrm{O}_{3}\right)$ forms a protective layer present in the earth's atmosphere and it is found in the lower portion of stratosphere, which is $\sim 12$ to $50 \mathrm{~km}$ above earth's surface. Discovered first by Charles Fabry and Henri Buisson in 1913, its properties were explored by G. M. B. Dobson. This layer acts as a shield to protect the earth against harmful ultraviolet (UV) radiation from the sun $[2,3]$. UV radiation is part of the solar electromagnetic spectrum, with wavelengths shorter than those of visible light, but longer than X-rays, and is widely known as a geno-

*Corresponding author. toxic environmental agent that affects ecosystem and human population [4]. Ozone, a variant of oxygen is a poisonous gas; and its formation and destruction is a continuous phenomenon. Ozone occurs at two levels, the stratospheric ozone and the tropospheric ozone. The tropospheric (ground) ozone varies with the daylight variations. Ozone near-ground is a pollutant and its production is enhanced due to air pollutants, like, nitrogen oxides (NOx) and volatile organic compounds (VOCs). The increase in terrestrial ozone particulates results in their enhanced scattering and improved absorption of UV-B radiations, which contributes to global warming by acting as a greenhouse gas and also shows harmful effects on both animals and plants. An increase in the UV-B radiation is one of the major causes for enhanced production of carbon monoxide from dead organic matter and release of nitrogen oxides. The ground ozone along with carbon monoxide is responsible for acid rain which causes damage to lung tissue and its long-term exposure can cause permanent tissue damage. Tree leaf and needle losses are linked to acidification and high percentage of 
ground ozone. Ground ozone concentration is lower in Polar and equatorial regions. The sub-tropical ground ozone concentration in Northern hemisphere is twice the corresponding region in Southern hemisphere [5].

Although, $\mathrm{O}_{3}$ is present in low concentration $(\sim 0.6$ $\mathrm{ppm}$ ) in the atmosphere, it plays an important role by efficiently screening out harmful radiations. The UV rays are of shorter wavelengths ranging from $100-280 \mathrm{~nm}$ (UV-C), 280 - $315 \mathrm{~nm}$ (UV-B) to 315 - $400 \mathrm{~nm}$ (UV-A). Of the UV rays, UV-C is completely absorbed by the ozone layer and only $5 \%$ of UV-B reaches the earth surface, while nearly $95 \%$ of UV-A is able to penetrate the atmospheric layers [6]. UV radiations affect all the elements of the biome including plants, pathogens, herbivores, carnivores and microorganisms. These radiations are harmless to DNA but can cause genetic damage to the skin and are responsible for increasing the total reactive oxygen level. UV-A can be further divided into UVA1 (340 - $400 \mathrm{~nm})$ and UV-A2 (320 - $340 \mathrm{~nm})$. UV-A1 radiations damage DNA through the generation of radical and non-radical reactive oxygen species (ROS) as an indirect response, while UV-A2 radiations can cause damage both indirectly as well as directly through generation of ROS and DNA photoproducts, respectively. The ROS so formed can actually lead to oxidative damage of DNA by the formation of 8-oxo-7, 8-dihydro-2'-deoxyguanosine and thymidine glycol, lipid peroxidation, and by cross-linking of proteins such as collagen. When human skin is exposed to UV-A radiation, cyclobutane pyrimidine dimers are produced in significant amount, leading to photo-carcinogenesis of the skin [7]. The UV-B radiations play a vital role in the synthesis of vitamin $\mathrm{D}$, which involves two steps: formation of pre-vitamin D and its thermo conversion. UV-B radiations exhibit the ability to transmute the biochemical and physiological pathways of cells by structural changes in biomolecules, which ultimately cause diseases such as skin cancer, photo-aging, immuno-suppression and cataracts in the human population. The ability of UV-B to penetrate water bodies affects the cellular DNA in phytoplankton, zooplankton and ichthyoplankton that led to increased mortality due to physiological anomalies [6]. The sunspot cycle leads to an increase in UV-B influxes during its various stages, which causes stratospheric temperature fluctuations. The solar maxima of the sun-spot cycle are responsible for increased UV-C radiation which stimulates the formation of stratospheric ozone.

The ozone depletion over the Antarctic has been noticed since 1970s and the Arctic region has also been witnessing the occurrence of an ozone-hole during the last decade. The overall depletion has been increasing at the rate of $0.5 \%$ per year since 2000 , because of the extensive use of ozone depleting substances (ODSs) such as propellants (in the manufacture of soft and hard foams), refrigeration, air conditioning and as cleaning solvents [8]. The atmospheric release of ODSs such as halocarbons including chlorofluorocarbons (CFCs), hydro-chlorofluorocarbons (HCFCs), hydro-fluorocarbons (HFCs) and bromofluorocarbons (BFCs) has led to a significant decrease of the ozone layer. Halocarbons are artificially synthesized gases consisting of carbon and one or more halogens (fluorine, chlorine, iodine and bromine) released in enormous amounts and they are responsible for an increased concentration of $\mathrm{Cl}$ and $\mathrm{Br}$ in the atmosphere [9]. CFCs (Freons) are a group of colorless, non-combustible liquids which are highly volatile substances and poorly soluble in water. Hence, they are mainly released into the air through evaporation during their production and use. These do not bind to soil strongly and thus they can easily leach to the groundwater. The use of these chemicals has been phased out because of their deleterious effects on ozone layer but they may still be found as an environmental hazard as they degrade slowly in groundwater.

CFCs are also found to have health effects which include short-term (acute) and long-term (chronic) effects. Exposure to pressurized CFCs can cause frostbites to the skin and to the upper airway if inhaled. At high temperature, they can degrade to more acutely toxic gases such as chlorine and phosgene. At high concentrations, inhalation of CFCs affects the central nervous system (CNS) with symptoms of alcohol-like intoxication, reduced coordination, light headedness, headaches and convulsions. Disturbances in heart rhythm can occur at very high concentrations and had even caused some deaths from intentional sniffing. Increased health impacts had been observed with the increase in CFCs concentration [10].

Apart from this, traces of gaseous nitrogen compounds, such as $\mathrm{NO}, \mathrm{NO}_{2}$ and $\mathrm{N}_{2} \mathrm{O}$, present in small quantities in the atmosphere are considered to be the largest ozonedepleting substances emitted by human activities exceeding the contribution of chlorofluorocarbons [11]. If these chemicals escape into the environment, they drift up the stratosphere where $\mathrm{Cl}$ and $\mathrm{Br}$ radicals are liberated by the action of ultraviolet light on their molecule and act as a catalyst affecting the ozone layer at $-78^{\circ} \mathrm{C}$ (critical temperature required by chlorine to breakdown ozone at surface of polar stratospheric cloud crystals), where they lead to a complete breakdown of ozone and thus reduce it to oxygen molecules. One chlorine or CFC molecule can destroy 100,000 ozone molecules. As a result the ozone layer becomes incapable of absorbing UV radiations which enter the earth's surface and affect various living organisms.

The CFCs have been phased out in both developed and developing countries since 1996 and 2010, respectively. Alternative to CFCs, HCFCs will also be phased out in both developed and developing nations by the year 2020 
and 2030, respectively. The World Meteorological Organization (WMO), 1995 predicted that the depletion of the ozone layer peaked around 1998 and the layer would slowly recover by 2045 [12]. But many researchers do not agree with these predictions $[13,14]$ and express their concern regarding a delayed recovery of stratospheric ozone [15]. Thus, at present the anthropogenic damage to the ozone layer strongly exceeds its recovery. There is a burgeoning need to reduce the production of industrial products causing ozone depletion and global warming.

The Vienna Convention for protection of Ozone layer was adopted by 43 nations in 1985. It addressed the importance of conservation of Ozone layer and established global mechanism for research, monitoring and exchange of information. Two months later, its adoption by the British scientists announced the presence of Ozone hole over Antarctic triggering concern about human safety. Nearly 60 plus countries met at Montreal in 1987 to come up with a protocol on curbing the Ozone Depleting Substances (ODSs). For the first time the CFCs were identified as a major culprit and CFCs-11, 12, 13, 114 and 115 and Halons-1211, 1301 and 2402 were targeted for reduction. The onus for reduction was more on developed countries, but to encourage developing countries for joining the protocol it was incentivized through favorable trade benefits. The 1990 London Amendment brought other ODSs into ambit for a total phase-out by 2000 , viz., Carbon tetrachloride, and trichloroethane. The signatories have been given ten year time for total phase out for enlisted ODSs. It has targeted to 2040 for a total phase out of all kinds of ODSs [16]. The Kyoto Protocol sought reduction of $\mathrm{CO}_{2}$ emissions and was signed in 1997. But, it became a trading house of carbon credits, which allowed developed countries to pass off their commitments onto the less developed countries, which had low emissions due to low development. The Kyoto takes 1990 as the base year for green-house gases emission levels (GHGs). In the case of hydrofluorocarbons (HFCs) and perfluorocarbons (PFCs) it is 1995. But, the base year has been fluctuating for individual countries [17].

\section{Consequences of Ozone Layer Depletion}

The ozone layer plays an important role in the biology and climatology of the earth's environment. Radiations below the wavelength of $3000 \AA$ are biologically harmful and ozone helps to filter-out these radiations. The stratospheric ozone layer protects life on earth by absorbing the damaging, high-energy UV-C radiation. Depletion of stratospheric ozone increases the concentration of terrestrial ozone, which is considered harmful for health. Ozone depletion resulted in global warming by increase of the atmospheric temperature by $5.5^{\circ} \mathrm{C}$ [18]. Exposure to UV rays due to ozone depletion causes innumerable biological hazards such as variation in the physiological and de- velopmental processes, reduced growth and productivity of plants. Indirect damage caused by the UV-B includes changes in the plant form and distribution of nutrients within the plant. These changes have important implications for plant competitive balance, herbivory, plant diseases, and biogeochemical cycles. Exposure to solar UV$\mathrm{B}$ radiation has been shown to affect both orientation mechanisms and mortality in phytoplankton, resulting in reduced survival rates for these organisms. Solar UV-B radiation has also been found to cause damage to the early developmental stages of fish, shrimp, crab, amphibians and other animals. Most severe effects are decreased reproductive capacity and impaired larval development. Increase in solar UV radiations affect terrestrial and aquatic biogeochemical cycles, thus altering both sources and sinks of greenhouse and chemically important trace gases such as carbon dioxide $\left(\mathrm{CO}_{2}\right)$, carbon monoxide $(\mathrm{CO})$, carbonyl sulphide (COS) and possibly other gases, including ozone. These potential changes would contribute to the biosphere-atmosphere feedbacks that attenuate or reinforce the atmospheric build-up of these gases. Synthetic polymers, naturally occurring biopolymers, as well as some other materials of commercial interest are adversely affected by solar UV radiation [19].

\subsection{Effects of Ozone Depletion on Plants}

A large number of negative effects of UV-B radiations on the global plant productivity due to stratospheric ozone depletion have been observed. Earlier studies report the loss of $50 \%$ crop plants in European countries due to UV-radiations that enter the earth's surface. It adversely affects the rate of photosynthesis in plants resulting in decreased agriculture production. UV-B radiations affect the plant's height, fresh weight, dry weight and its ash contents which reflect the deleterious effects of UV-B on crop plants [20]. UV enhances the rate of evaporation through stomata and results in decreased soil moisture content thus, ultimately affects the growth and development of crop plants. Ozone depletion adversely affects the weather which influences the crop production due to plant injury and development of various diseases [13]. The leaf expansion is also inhibited by UV radiations [21-23]. Other morphogenetic effects include reduced leaf size, increased leaf thickness [24-26] and leaf mass per unit area $[27,28]$, accumulation of leaf surface waxes [29] and reduction in the total number of leaf (observed in species Cucumis sativus and Lactuca sativus) [30,31]. Besides morphological variations in response to UV-B, anatomical changes in plants such as injury or death of epidermal cells have also been reported. Leaf browning or bronzing in beans, leaf desiccation in collards, radish, cucumber, squash and epinasty of leaves in beans have also been observed [21]. However, recent studies focus on utilization of UV-B radiations, for modified resistance 
to pest and disease attack, and increased global crop production by alterations in the secondary metabolism, enhanced photo-protection, and up-regulation of antioxidative response [32]. Bacteria are sensitive to ultraviolet radiations and hence are killed instantly in the presence of UV light. The ozone reduction affects the cyanobacterial growth in rhizospheric zone of legumenous plants, which helps in retaining nitrogen content and thus gets adversely affected [33]. Recent studies clearly indicate that UV radiations can be exploited as a major tool for enhancing crop growth and production by exogenous application of phytohormones on growing plants and seeds [34-36].

Extensive studies have been carried out to know the adverse effects of UV-B radiations on the plant morphology, physiological processes and on biologically important molecules such as the nucleic acid, proteins, pigments and lipids [37-41]. UV-B radiations do not affect the seed germination in most of weedy species due to presence of hard seed coat [42]. Lactuca sativa showed improved seed germination when exposed to 254, 265, 334 and $405 \mathrm{~nm}$ of radiations as compared to those grown in dark [43]. However, rapid seed germination and highly branched roots were observed in kale, cabbage, radish and agave seeds when treated with UV radiation when compared to the control [44]. A study on cotton (Gossypium hirsutum) showed that excess UV-B damages the developing shoots of cotton resulting in the reduction of dry matter, $\mathrm{Zn}$ mobilization and leaf expansion [45]. UV-B radiations inhibit the radical elongation but shoot growth is not affected by these radiations which indicate that roots are more sensitive to UV light. Exposure to some UV-B radiations during the day time may result in the selection of more efficient UV-protection mechanism which makes shoots less susceptible to the harmful effects of these radiations.

All the species respond differently to UV-B radiation under different experimental approaches as the effects are either stimulating, depressing, or have no effect on their growth and physiology [8,19,42-46]. Availability of water influences the effect of UV-B on bryophytes as these are poikilohydric and unavailability of water causes leaf cells to dry out and ceases the metabolism [47]. Desiccation tolerance in many bryophytes might be assisted by the development of antioxidant and photo-protection mechanisms that scavenges or minimizes the production of reactive oxygen species. Various experiments have been carried out that showed variability in the bryophyte percentage cover, sporophyte abundance, annual growth, sclerophylly index (quotient between shoot mass and surface area of fresh prostrate apex), and chlorophyll concentration of different species under drier and mesic sites [48]. There have been several studies during the last decade which elucidate the negative implications of UV re- sponse on the plant development. These inferences are based on the studies that have frequently used unbalanced spectral manipulations, unrealistically high supplementary fluxes and in vitro exposures of single cellular components. This has introduced ambiguity to overall perception of UV radiation as a stimulus for the plant development. The significant questions remain with regard to the various consequences of UV radiation for agro-ecosystems and other ecological systems. Many studies using a wide range of pathogens have demonstrated that UV can also kill fungal spores and inhibit their germination $[49,50]$.

\subsection{Effects of UV-B Radiations on Aquatic and Terrestrial Ecosystem}

Ozone layer plays an important role in the evolution of terrestrial plants by the development of phenolic polymer metabolism induced by UV-B [51]. Flavonoids and lignin present in gymnosperms and angiosperms (but absent in algae) are the major products of this metabolism. The solar UV radiations stimulate the enzymes such as PAL (Phenylalanine Ammonium Lyase) and CHS (Chalcone Synthase) that catalyses transformation of phenylalanine to trans-cinnamic acid. This results in the formation of complex phenolic compounds such as flavonoids, lignins and tannins. Accumulation of these compounds reduces the penetration of UV wavelengths deeper into the leaves thus protects photosynthetic machinery and other essential components from damage [24,52]. Hence these compounds acts as UV screen and make plants resistant to solar UV. It has been inferred that plant cells receive damage from exposure to UV-B as it induces change in the proteins and nuclear DNA. Young bud and leaves are considered more susceptible than the mature plant parts. Although there are still inconclusive observations of UV induced photo-morphogenesis particularly with regard to signal transduction and other early stage responses. As DNA is a strong UV absorbent [53], accumulation of flavonoids provides photo-protection to limit DNA damage $[51,54,55]$ and the photo-repair of DNA lesions through photo-reactivation processes [56]. The variability in UV radiations on earth had partly governed the evolution of plants and animals [51]. Eco-physiological studies have provided sufficient evidence suggesting that the plant growth inhibition, caused by the high and ambient doses of ultraviolet radiations could be related to DNA damage leading to various mutations and neoplasia $[18,19]$. DNA damage indicates acute effects of short exposures to UVB because short-wave UV radiation can disturb most biological macromolecules, including proteins, lipids, and nucleic acids. UV-B effects on DNA are also responsible for cryptic transposable elements in some species, which might result into mutations beyond the extent of immediate DNA damage [15]. Studies in animal systems suggest 
that damage to DNA is the principal cause of cell death and degeneration.

\subsection{Effects of Ozone Depletion on Human Society}

Exposure of UV radiations leads to the formation of patches on skin and weakens human immune system. The UV radiations damage skin either by damaging melanocyte cells or by causing sun-burns due to faster flow of blood in capillaries of exposed areas. Malignant melanoma, a type of skin cancer is also caused by UV exposure which is less common but far more dangerous. Its relationship with UV exposures has not been understood yet but it is thought both UV-A and UV-B are involved [57]. Studies showed $10 \%$ increase in UV-B resulted in $19 \%$ increase in melanomas in men and $16 \%$ in women. More than one million new cases of non-melanoma skin cancers are reported in the US only. The susceptibility to cancer is often conspicuous in xeroderma pigmentosum, a disorder leading to extreme photosensitivity and early onset of cutaneous malignancies. It may also cause leukemia and breast cancer. UV exposure to human eye damages cornea and lens leading to photokeratitis, cataract and/or even blindness. Emphysema, bronchitis, asthma and even obstruction of lungs may be caused on exposure of UV light to human beings. Excess of UV light exposure causes DNA breakage, inhibition and alteration of DNA replication and premature ageing in humans [32]. Basal and squamous cell carcinomas are the most common type of cancers in humans due to excess UV exposure. The mechanism involved for the induction of these cancers by UV light includes absorption of UV-B radiation causes the pyrimidine bases in the DNA molecule to form dimers, resulting in transcriptional errors during DNA replication. These cancers are rarely fatal. Scientists estimate that every $1 \%$ decrease in stratospheric ozone would increase the incidences of these cancers by $2 \%$ [58]. Increased surface UV leads to increased tropospheric ozone which is a health risk as ozone is toxic due to its strong oxidant properties [59]. Besides producing vitamin D, UV-B radiation itself is correlated with skin cancer, photoaging, immuno-suppression and cataracts, to mention just a few of the harmful effects. Nevertheless, the overproduction, leads to the degradation of already formed vitamins, thereby attaining toxic levels and is associated with high mortality [60].

\section{Conclusion}

A large number of environmental problems such as ozone depletion and global warming are associated with increased development and economic growth throughout the world during the last century. The halocarbon refrigerants used in the refrigeration and air-conditioning systems have become a subject of great concern for the last few decades. The earth is the only planet that supports life, and thus preserving ozone layer and reducing the release of greenhouse gasses are the essential steps required for the protection of life. The stratospheric ozone helps in limiting the influx of harmful UV-B and greenhouse gas. UV radiation imposes a significant influence on the growth and development of fungi, plants and humans. The fungal diseases on plants have receding effects due to the inhibition of sporulation caused by exposure to UV radiation. In plants, UV radiations resulted in reduced plant height, fresh-weight, dry-weight, seed germination and seedling growth. The plants also showed mutant formation that alters the growth properties which are detrimental to optimal utilisation of the plant products. The exposure of humans to UV can lead to various diseases such as skin cancer, cataract and mutant DNA. There have been a significant number of studies till date which have described negative implications of UV response for plant development. However, numerous studies have also reported the positive aspects of UV radiations wherein it plays an important role in the evolution of plant and animal species. Therefore, one has to take the larger argument of the protective role of ozone layer along with its phytogenic response. For this purpose, different conventions and protocols have been adopted to control ozone depletion and its impacts on all life forms. These include Vienna Convention in 1985 followed by the Montreal Protocol in 1987 and the Kyoto Protocol in 1997. These protocols banned the use of ozone depleting substances (ODSs) in both developed and developing countries. Chlorofluorocarbons (CFCs) have been found to be the main cause of ozone depletion and have many health impacts. Stratospheric ozone depletion leads to the formation of a secondary ozone layer near ground called terrestrial ozone. Air pollutants enhance the production of ground ozone. Terrestrial ozone acts as a green-house gas and leads to global warming by the absorption of solar UV-B radiations.

\section{Acknowledgements}

The authors gratefully acknowledge Dr. P. Hemalatha Reddy, Principal (Sri Venkateswara College) University of Delhi for providing institutional support.

\section{REFERENCES}

[1] Committee on Solar-Terrestrial Research, "Solar-Terrestrial Research for the 1980's," A Report, National Research Council, National Academy Press, Washington DC, 1981.

[2] World Meteorological Organization (WMO), "Scientific Assessment of Ozone Depletion: Report No. 44," World Meteorological Organization, Geneva, 1998. 
[3] Y. Matsumi and M. Kawasaki, "Photolysis of Atmospheric Ozone in the Ultraviolet Region," Chemical Reviews, Vol. 103, No. 12, 2003, pp. 4767-4781. http://dx.doi.org/10.1021/cr0205255

[4] T. Yagura, K. Makita, H. Yamamoto, C. F. M. Menck and A. P. Schuch, "Biological Sensors for Solar Ultraviolet Radiation," Sensors (Basel), Vol. 11, No. 4, 2011, pp. 4277-4294. http://dx.doi.org/10.3390/s110404277

[5] "Blueprint 4: Capturing Global Environmental Value by David William Pearce," Earthscan Publications, London, 1995.

[6] J. Tian and Y. Juan, "Changes in Ultrastructure and Responses of Antioxidant Systems of Algae (Dunaliella salina) during Acclimation to Enhanced Ultraviolet-B Radiation," Journal of Photochemistry and Photobiology B: Biology, Vol. 97, No. 3, 2009, pp. 152-160. http://dx.doi.org/10.1016/j.jphotobiol.2009.09.003

[7] A. T. Dinkova-kostova, "Phytochemicals as Protectors against Ultraviolet Radiation: Versatility of Effects and Mechanisms," Planta Medica, Vol. 74, No. 13, 2008, pp. 1548-1559. http://dx.doi.org/10.1055/s-2008-1081296

[8] J. Rozema, P. Boelen and P. Blokker, "Depletion of Stratospheric Ozone over the Antarctic and Arctic: Responses of Plants of Polar Terrestrial Ecosystems to Enhanced UV-B, an Overview," Environmental Pollution, Vol. 137, No. 3, 2005, pp. 428-442.

http://dx.doi.org/10.1016/j.envpol.2005.01.048

[9] B. O. Bolaji and Z. Huan, "Ozone Depletion and Global Warming: Case for the Use of Natural Refrigerant-A Review," Renewable \& Sustainable Energy Reviews, Vol. 18, 2013, pp. 49-54. http://dx.doi.org/10.1016/j.rser.2012.10.008

[10] Chlorofluorocarbons (CFCs), "Health Information Summary. Environmental Fact Sheet. New Hampshire Department of Environmental Services," 2010.

[11] A. R. Ravishankara, J. S. Daniel and R. W. Portmann, "Nitrous Oxide $\left(\mathrm{N}_{2} \mathrm{O}\right)$ : The Dominant Ozone-Depleting Substance Emitted in the $21^{\text {st }}$ Century," Science, Vol. 326, No. 5949, 2009, pp. 123-125.

http://dx.doi.org/10.1126/science.1176985

[12] World Meteorological Organization Global Ozone Research and Monitoring Project, "Scientific Assessment of Ozone Depletion: 1994," Report 37, World Meteorological Organization, Geneva, 1995.

[13] D. J. Allen, S. Nogues and N. R. Baker, "Ozone Depletion and Increased UV-B Radiation: Is There a Real Threat to Photosynthesis," Journal of Experimental Botany, Vol. 49 No. 328, 1998, pp. 1775-1788. http://dx.doi.org/10.1093/jxb/49.328.1775

[14] O. Greene, "Emerging Challenges for Montreal Protocol," Globe, Vol. 27, 1995, pp. 5-6.

[15] D. T. Shindell, D. Rind and P. Lonergan, "Increased Polar Stratospheric Ozone Losses and Delayed Eventual Recovery Owing to Increasing Greenhouse-Gas Concentration," Nature, Vol. 292, No. 6676, 1998, pp. 589-592. http://dx.doi.org/10.1038/33385

[16] "Planning, Designing and Implementing Policies to Control Ozone Depleting UNEP Publication," 2003.
[17] S. Oberthür and H. E. Ott, "The Kyoto Protocol: International Climate Policy for the 21st Century," Springer, Berlin, 1999.

[18] United Nations Environment Programme, "Environmental Effects Assessment Panel, Environmental Effects of Ozone Depletion and Its Interactions with Climate Change,' Progress Report, 2010.

[19] K. K. Newsham and S. A. Robinson, "Responses of Plants in Polar Regions to UV-B Exposure: A Meta-Analysis," Global Change Biology, Vol. 15, No. 11, 2009, pp. 2574 2589. http://dx.doi.org/10.1111/j.1365-2486.2009.01944.x

[20] F. M. Basiouny, "Effects of UV-B Irradiation on Growth and Development of Different Vegetable Crops," Proceedings of Florida State Horticultural Society, Vol. 95, 1982, pp. 356-359.

[21] R. González, R. Mepsted, A. R. Wellburn and N. D. Paul, "Non-Photosynthetic Mechanism of Growth Reduction in Pea (Pisum sativum L.) Exposed to UV-B Radiation," Plant, Cell \& Environment, Vol. 21, No. 1, 1998, pp. 2332. http://dx.doi.org/10.1046/j.1365-3040.1998.00243.x

[22] C. T. Ruhland and T. A. Day, "Effects of Ultraviolet-B Radiation on Leaf Elongation, Production and Phenylpropanoid Concentration of Deschampsia antarctica and Colobanthus quitensis in Antarctica," Plant Physiology, Vol. 109, No. 3, 2000, pp. 244-251. http://dx.doi.org/10.1034/j.1399-3054.2000.100304.x

[23] P. S. Searles, S. D. Flint and M. M. Caldwell, "A Metaanalysis of Plant Field Studies Simulating Stratospheric Ozone Depletion," Oecologia, Vol. 127, No. 1, 2001, pp. 1-10. http://dx.doi.org/10.1007/s004420000592

[24] T. F. Bornman and T. C. Vogelmann, "Effects of UV-B Radiation on Leaf Optical Properties Measured with Fiber Optics," Journal of Experimental Botany, Vol. 42, No. 4, 1991, pp. 547-554. http://dx.doi.org/10.1093/jxb/42.4.547

[25] I. Staxén and J. F. Bornman, "A Morphological and Cytological Study of Petunia hybrida Exposed to UV-B Radiation," Plant Physiology, Vol. 91, No. 4, 1994, pp. 735740 .

http://dx.doi.org/10.1111/j.1399-3054.1994.tb03013.x

[26] J. Rozema, A. Chardonnens, M. Tosserams, R. Hafkenscheid and S. Bruijnzeel, "Leaf Thickness and UV-B Absorbing Pigments of Plants in Relation to an Elevational Gradient along the Blue Mountains, Jamaica," Plant Ecology, Vol. 128, No. 1-2, 1997, pp. 151-159. http://dx.doi.org/10.1023/A:1009719109153

[27] M. Šprtova, V. Špunda, J. Kalina and M. V. Marek, "Photosynthesis UV-B Response of Beech (Fagus sylvatica L.) Saplings," Photosynthetica, Vol. 41, No. 4, 2003, pp. 533543.

http://dx.doi.org/10.1023/B:PHOT.0000027517.80915.1b

[28] R. Láposi, S. Veres, G. Lakatos, V. Oláh, A. Fieldsend and I. Mészáros, "Responses of Leaf Traits of European Beech (Fagus sylvatica L.) Saplings to Supplemental UV-B Radiation and UV-B Exclusion," Agricultural and Forest Meteorology, Vol. 149, No. 5, 2009, pp. 745-755. http://dx.doi.org/10.1016/j.agrformet.2008.10.023

[29] Y. P. Cen and J. F. Bornman, "The Effect of Exposure to 
Enhanced UV-B Radiation on the Penetration of Monochromatic and Polychromatic UV-B Radiation in Leaves of Brassica napus," Plant Physiology, Vol. 87, No. 3, 1993, pp. 249-255.

http://dx.doi.org/10.1111/j.1399-3054.1993.tb01727.x

[30] D. T. Krizek, R. M. Mirecki and S. J. Britz, "Inhibitory Effects of Ambient Levels of Solar UV-A and UV-B Radiation on Growth of Cucumber," Plant Physiology, Vol. 100, No. 4, 1997, pp. 886-893. http://dx.doi.org/10.1111/j.1399-3054.1997.tb00014.x

[31] D. T. Krizek, S. J. Britz and R. M. Mirecki, "Inhibitory Effects of Ambient Levels of Solar UV-A and UV-B Radiation on Growth of cv. New Red Fire Lettuce," Plant Physiology, Vol. 103, No. 1, 1998, pp. 1-7. http://dx.doi.org/10.1034/j.1399-3054.1998.1030101.x

[32] J. J. Wargent and B. R. Jordan, "From Ozone Depletion to Agriculture: Understanding the Role of UV Radiation in Sustainable Crop Production," New Phytologist, Vol. 197, No. 4, 2013, pp. 1058-1076. http://dx.doi.org/10.1111/nph.12132

[33] R. P. Sinha, S. C. Singh and D. P. Häder, "Photoecophysiology of Cyanobacteria," Recent Research Developments in Photochemistry and Photobiology, Vol. 3, 1999, pp. 91-101.

[34] M. Hulten, M. Pelser, L. C. van Loon, C. M. J. Pieterse and J. Ton, "Costs and Benefits of Priming for Defence in Arabidopsis," Proceedings of the National Academy of Sciences, Vol. 103, No. 14, 2006, pp. 5602-5607. http://dx.doi.org/10.1073/pnas.0510213103

[35] D. Worrall, G. H. Holroyd, J. P. Moore, M. Glowacz, P. Croft, J. E. Taylor, N. D. Paul and M. R. Roberts, "Treating Seeds with Activators of Plant Defence Generates LongLasting Priming of Resistance to Pests and Pathogens," New Phytologist, Vol. 193, No. 3, 2012, pp. 770-778. http://dx.doi.org/10.1111/j.1469-8137.2011.03987.x

[36] W. J. Davies, J. Zhang, J. Yang and I. C. Dodd, "Novel Crop Science to Improve Yield and Resource Use Efficiency in Water-Limited Agriculture," The Journal of Agricultural Science, Vol. 149, No. S1, 2011, pp. 123131.

[37] P. W. Barnes, S. D. Flint and M. M. Caldwell, "Morphological Responses of Crop and Weed Species of Different Growth Forms to Ultraviolet-B Radiation," American Journal of Botany, Vol. 77, No. 10, 1990, pp. 1354-1360. http://dx.doi.org/10.2307/2444596

[38] M. A. K. Jansen, V. Gaba and B. M. Greenberg, "Higher Plants and UV-B Radiation: Balancing Damage, Repair and Acclimation," Trends in Plant Science, Vol. 3, No. 4, 1998, pp. 131-135. http://dx.doi.org/10.1016/S1360-1385(98)01215-1.

[39] V. C. Runeckles and S. V. Krupa, "The Impact of UV-B Radiation and Ozone on Terrestrial Vegetation," Environmental Pollution, Vol. 83, No. 1-2, 1994, pp. 191-213.

[40] A. H. Teramura, "Effects of Ultraviolet-B Radiation on the Growth and Yield of Crop Plants," Physiologia Plantarum, Vol. 58, No. 3, 1983, pp. 415-427. http://dx.doi.org/10.1111/j.1399-3054.1983.tb04203.x

[41] D. P. Ormrod, A. M. Schmidt and N. J. Livingston, "Effects of UV-B Radiation on the Shoot Dry Matter Pro- duction and Stable Carbon Isotope Composition of Two Arabidopsis thaliana Genotypes," Physiologia Plantarum, Vol. 101, No. 3, 1996, pp. 497-502. http://dx.doi.org/10.1111/j.1399-3054.1997.tb01029.x

[42] T. V. Callaghan, L. O. Björn, Y. T. Chernov, T. R. Chapin, B. Christensen, R. A. Huntley, M. Ims, D. Johansson, S. Jolly, N. Jonasson, N. Matveyeva, W. Panikov, G. Oechel, J. Shaver, I. S. Elster, K. Jónsdóttir, K. Laine, E. Taulavuori and C. Zöckler, "Responses to Projected Changes in Climate and UV-B at the Species Level," Ambio, Vol. 33, No. 7, 2004, pp. 418-435. http://dx.doi.org/10.1579/0044-7447-33.7.418

[43] C. Wagne, "Effect of UV Light on Lettuce Seed Germination and on the Unfolding of Grass Leaves," Physiologia Plantarum, Vol. 19, No. 1, 1966, pp. 128-133. http://dx.doi.org/10.1111/j.1399-3054.1966.tb09083.x

[44] R. E. Noble, "Effects of UV-B Irradiation on Seed Germination," Science of the Total Environment, Vol. 299, No. 1-3, 2002, pp. 173-176. http://dx.doi.org/10.1016/S0048-9697(02)00232-2

[45] J. E. Ambler, D. T. Krizek and P. Semeniuk, "Influence of UV-B Radiation on Early Seedling Growth and Translocation of $\mathrm{Zn}$ from Cotyledons in Cotton," Physiologia Plantarum, Vol. 34, No. 3, 1975, pp. 177-181. http://dx.doi.org/10.1111/j.1399-3054.1975.tb03816.x

[46] P. Boelen, M. K. De Boer, N. V. J. De Bakker and J. Rozema, "Outdoor Studies on the Effects of Solar UV-B on Bryophytes: Overview and Methodology," Plant Ecology, Vol. 182, No. 1-2, 2006, pp. 137-152. http://dx.doi.org/10.1007/s11258-005-9023-1

[47] M. C. F. Proctor, "Physiological Ecology," In: B. Goffinet and A. J. Shaw, Eds., Bryophyte Biology, Cambridge University Press, Cambridge, pp. 237-268.

[48] M. Arróniz-Crespo, D. Gwynn-Jones, T. V. Callaghan, E. Núñez-Olivera, J. Martínez-Abaigar, P. Horton and G. K. Phoenix, "Impacts of Long-Term Enhanced UV-B Radiation on Bryophytes in Two Sub-Arctic Heathland Sites of Contrasting Water Availability," Annals of Botany, Vol. 108, No. 3, 2011, pp. 557-565. http://dx.doi.org/10.1093/aob/mcr178

[49] A. J. Caesar and R. C. Pearson, "Environmental Factors Affecting Survival of Ascospores of Sclerotinia sclerotiorum," Phytopathology, Vol. 73, 1983, pp. 1024-1030. http://dx.doi.org/10.1094/Phyto-73-1024

[50] T. S. Gunasekera, N. D. Paul and P. G. Ayres, "The Effects of Ultraviolet-B (UV-B, 290-320 nm) Radiation on Blister Blight Disease of Tea (Camellia sinensis L.)," Plant Pathology, Vol. 46, No. 2, 1997, pp. 179-185. http://dx.doi.org/10.1046/j.1365-3059.1997.d01-216.x

[51] J. Rozema, L. O. Björn, J. F. Bornman, A. Gaberščik, D. P. Häder, T. Trošt, M. Germ, M. Klisch, A. Gröniger, R. P. Sinha, M. Lebert, Y. Y. He, R. Buffoni-Hall, N. V. de Bakker, J. van de Staaij and B. B. Meijkamp, "The Role of UV-B Radiation in Aquatic and Terrestrial Ecosystems -An Experimental and Functional Analysis of the Evolution of UV-B Absorbing Compounds," Journal of Photochemistry and Photobiology B: Biology, Vol. 66, No. 1, 2002, pp. 2-12.

http://dx.doi.org/10.1016/S1011-1344(01)00269-X 
[52] T. A. Day, G. Martin and T. C. Vogelmann, "Penetration of UV-B Radiation in Foliage-Evidence that the Epidermis Behaves as a Non-Uniform Filter," Plant, Cell \& Environment, Vol. 16, No. 6, 1993, pp. 735-741.

[53] R. M. Taylor, O. Nikaido, B. R. Jordan, J. Rosamond, C. M. Bray and A. K. Tobin, "Ultraviolet-B-Induced DNA Lesions and Their Removal in Wheat (Triticum aestivum L.) Leaves," Plant, Cell \& Environment, Vol. 19, No. 2, 1996, pp. 171-181. http://dx.doi.org/10.1111/j.1365-3040.1996.tb00238.x

[54] A. E. Stapleton and V. Walbot, "Flavonoids Can Protect Maize DNA from the Induction of Ultraviolet Radiation Damage," Plant Physiology, Vol. 105, No. 3, 1994, pp. 881-889. http://dx.doi.org/10.1104/pp.105.3.881

[55] C. A. Mazza, H. E. Boccalandro, C. V. Giordano, D. Battista, A. L. Scopel and C. L. Ballaré, "Functional Significance and Induction by Solar Radiation of Ultraviolet Absorbing Sunscreens in Field-Grown Soybean Crops," Plant Physiology, Vol. 122, No. 1, 2000, pp. 117-125. http://dx.doi.org/10.1104/pp.122.1.117

[56] C. Z. Jiang, J. Yee, D. L. Mitchell and A. B. Britt, "Pho- torepair Mutants of Arabidopsis," Proceedings of the National Academy of Sciences of the United States of America, Vol. 94, No. 14, 1997, pp. 7441-7445. http://dx.doi.org/10.1073/pnas.94.14.7441

[57] R. B. Setlow, E. Grist, K. Thompson and A. D. Woodhead, "Wavelengths Effective in Induction of Malignant Melanoma," Proceedings of the National Academy of Sciences of the United States of America, Vol. 90, No. 14, 1993, pp. 6666-6670.

[58] F. R. de Gruijl, "Impacts of a Projected Depletion of the Ozone Layer," Consequences, Vol. 1, No. 2, 1995, pp. 120.

[59] T. R. Fears, C. C. Bird, D. Guerry, R. W. Sagebiel, M. H. Gail, D. E. Elder, A. Halpern, E. A. Holly, P. Hartge and M. A. Tucker, "Average Midrange Ultraviolet Radiation Flux and Time Outdoors Predict Melanoma Risk," Cancer Research, Vol. 62, No. 14, 2002, pp. 3992-3996.

[60] R. Vieth, "Vitamin D Supplementation, 25-Hydroxyvitamin D Concentrations, and Safety," The American Journal of Clinical Nutrition, Vol. 69, No. 5, 1999, pp. 842856.

\section{List of Abbreviations Used}

$\begin{array}{ll}\text { ROS } & \text { Reactive Oxygen Species } \\ \text { CFC } & \text { Chlorofluorocarbon } \\ \text { UV } & \text { Ultraviolet } \\ \text { HCFC } & \text { Hydro Chlorofluorocarbon } \\ \text { WMO } & \text { World Meteorological Organisation } \\ \text { ODS } & \text { Ozone Depleting Substances } \\ \text { BFC } & \text { Bromofluorocarbon } \\ \mathrm{CO}_{2} & \text { Carbon Dioxide } \\ \mathrm{CO} & \text { Carbon Monoxide } \\ \mathrm{COS} & \text { Carbonyl Sulphide } \\ \text { PAL } & \text { Phenylalanine Ammonium Lyase } \\ \mathrm{CHS} & \text { Chalcone Synthase } \\ \mathrm{HFC} & \text { Hydro-Fluorocarbon } \\ \text { DNA } & \text { Deoxyribonucleic Acid } \\ \mathrm{Cl} & \text { Chlorine }\end{array}$

$\begin{array}{ll}\mathrm{Br} & \text { Bromine } \\ \mathrm{Zn} & \text { Zinc } \\ \mathrm{NO} & \text { Nitrogen Oxide } \\ \mathrm{NO}_{2} & \text { Nitrogen dioxide } \\ \mathrm{N}_{2} \mathrm{O} & \text { Nitrous Oxide } \\ \mathrm{C} & \text { Carbon } \\ \mathrm{US} & \text { United States } \\ \mathrm{CNS} & \text { Central Nervous System } \\ \text { VOC } & \text { Volatile Organic Compounds } \\ \text { GHGs } & \text { Green-House Gases } \\ \text { PFCs } & \text { Perfluorocarbons } \\ \mathrm{O}_{3} & \text { Ozone } \\ \mathrm{nm} & \text { Nanometer } \\ \text { ppm } & \text { Particle per Million }\end{array}$

